\title{
Work ethics of different generational cohorts in South Africa
}

\section{Author:}

Freda van der Walt ${ }^{1}$

Petronella Jonck ${ }^{2}$

Ntomzodwa Caroline

Sobayeni ${ }^{1}$

\section{Affiliation:}

${ }^{1}$ Central University of Technology, Free State, South Africa

${ }^{2}$ The National School of Government, Pretoria, South Africa

\section{Correspondence to:}

Dr. Freda van der Walt, Department of Business Management,

Central University of Technology,

P.O. Box 1881,

Welkom 9459,

South Africa

Tel. no.:

+27579103617

E-mail:

fvdwalt@cut.ac.za

DOI:

10.15249/10-1-101

\section{Keywords:}

generational differences; work ethics; Generation Y; Generation X; Baby Boomers; hard work; delay of gratification; morality; ethics

\section{Abstract}

Although generational differences have been studied in developed countries, not much information is available about generational cohorts and how they differ in terms of work ethics in developing countries. A cross-sectional study was conducted in 2014 with a sample of 301 respondents from South Africa. The work ethics of three generational cohorts, namely the Baby Boomers, Generation X and Generation Y, were measured. The main finding of this research was that statistically significant differences and similarities were found between the different generational cohorts in terms of certain facets of work ethics. Statistically significant generational differences were indicated for hard work and delay of gratification.

\section{Introduction}

The decline in ethical behaviour in corporate South Africa is concerning. In an economy that is on the verge of a recession, additional burdens are being placed on employees, which often leads to them cutting corners, breaking rules, and engaging in questionable practices (Robbins, Judge, Odendaal \& Roodt, 2009:16). It has been asserted that unethical behaviour, mainly in the form of corruption, particularly bribery, has reached "crisis proportions" within the South African context (Patel, 2013:1). Thus, it is becoming increasingly difficult to make ethical decisions, or to objectively assess the implications of a decision, in an environment that is rife with unethical behaviour.

Davis (2009:161) posits that ethical behaviour may be influenced by historical events and diversity variables, such as culture and age. In accordance with global trends, the South African workforce is becoming increasingly diverse, consisting 
of employees from different age groups, genders, ethnicities, cultural backgrounds, values, and beliefs, to mention a few of the variables (Robbins et al., 2009:12; Van der Walt \& Du Plessis, 2010:1). In addition, as a result of globalisation, many organisations conceive and design products in one country, produce said products in another country, and then market them globally, giving rise to numerous dyadic relationships (Jonck \& Swanepoel, 2015:78; Triandis, 2006:20). Due to the diverse nature of contemporary workforces worldwide, internationally in recent years much attention has been given to generational differences in the workplace. In a study by Burke (2004:4), 58\% of human resource management practitioners reported conflict between younger employees and mature employees, due to differences such as perceptions of work ethics and aspects related to work-life balance. As such, a study by Meriac, Woehr and Banister (2010:315) reported that ideological and perceptual differences between generational cohorts led to conflict and misunderstandings. Consequently, organisational leaders need to be aware of these differences that exist between different generations. This will not only lead to appropriate prevention or management of conflict, but also a reduction in the number of misunderstandings, which will be conducive to organisational effectiveness (Van der Walt \& Du Plessis, 2010:3).

In order to move South African society and its workplaces forward, more emphasis should be placed on work ethics, and, specifically, the advancement of ethical behaviour through human resource policies. Although some scholars have established that generations differ in terms of work ethics (Miller, Woehr \& Hudspeth, 2002:2; Twenge, 2010:201), not nearly enough research has been conducted to test whether generational differences with regard to work ethics are present in the South African work environment.

In light of the background discussed above, organisational leadership needs to comprehend that a different approach may be required to successfully attract new employees, and to effectively manage and retain current human capital. Although considerable research has been conducted on diversity management (e.g. Bell, Villado, Lukasik, Belau \& Briggs, 2011; De Wit, Greer \& Jehn, 2012; Strydom \& Erwee, 1998), there is a paucity of studies that have focused on generational or age diversity (Van der Walt \& Du Plessis, 2010:1). Establishing whether different generations have different work ethics would assist organisational leadership in formulating strategic human resource interventions, such as retention and procurement strategies.

\section{Generational cohort theory}

Generational cohort theory is regarded as a theory of social history that describes and elaborates on differences and changes in generational and public attitudes over time (Wolf, Carpenter \& Qenani-Petrela, 2005:187). Informed by the work of Mannheim (1964), this theory underscores two elements that are central to the conception of a generation, namely a shared location in historical time and a distinctive awareness of said historical time, shaped by events and experiences that are characteristic of that time.

Generational cohorts are individuals from the same generation, who have been exposed to the same external environment and events, which may potentially influence their 
behaviour and way of thinking (Napoli, 2014:184). Research investigating generational cohorts is based on the premise that each generation experiences a common and distinctive combination of circumstances and environmental forces that are prevalent during their formative years and which shape their behaviour patterns, distinguishing them from the behaviour patterns of other generations (Bevan-Dye, 2012:37). However, individual differences are acknowledged and one should guard against generalising behaviour. Moreover, there seems to be generational time span differences between different countries. The exact time span of the different generations according to country of origin is depicted in Table 1.

Table 1: Generational cohorts according to country

\begin{tabular}{l|c|c|c|c}
\hline \multicolumn{1}{c}{ Generation } & South Africa & USA & Europe/UK & Japan \\
\hline The Traditionalists & $1930-1949$ & $1923-1942$ & $1918-1945$ & $1925-1945$ \\
\hline The Baby Boomers & $1950-1969$ & $1943-1962$ & $1946-1965$ & $1945-1965$ \\
\hline Generation X & $1970-1989$ & $1963-1983$ & $1966-1984$ & $1966-1985$ \\
\hline Generation Y & $1990-2000$ & $1984-2001$ & $1985-2001$ & $1986-2001$ \\
\hline
\end{tabular}

Generation Z: born between 2001-2020

Source: Codrington \& Grant-Marshall, 2006:19

Within generational cohort theory, two opposing perspectives are held, namely that a generation is seen as consistent, regardless of different societies, or that a generation underscores the differences that may potentially exist between generational cohorts, due to the society in which they are cultivated. Turbulent life changes and/or important events that occur in a particular era (for example a war, or the abolition of apartheid) can shape a cohort living at the time (Codrington \& Grant-Marshall, 2006:11). Furthermore, internalisation of the ideas characteristic of that time may result in stereotyping of members of that particular generational cohort. Table 2 provides a brief summary of the characteristics of the different generational cohorts (Gursoy, Maier \& Chi, 2008:451; Robbins et al., 2009:102; Roux, 2008:20).

Table 2: Characteristics of the different generational cohorts

\begin{tabular}{l|l}
\hline \multicolumn{1}{c}{ Generation } & \multicolumn{1}{c}{ Characteristics } \\
\hline The Traditionalists & $\begin{array}{l}\text { Disciplined, hard-working, dedicated, respect authority and rules, loyal, stable, } \\
\text { conservative lifestyle, directive, respect positional power, and self-sacrificing. }\end{array}$ \\
\hline Generation X & $\begin{array}{l}\text { Open-minded, workaholic, ambitious, optimistic, success-driven and crave job } \\
\text { status, service-orientated, self-driven, build good relations, have team loyalty, } \\
\text { live to work, respect authority, and live large. }\end{array}$ \\
\hline Generation $Y$ & $\begin{array}{l}\text { Individualistic, self-reliant, pragmatic, hard-working and enthusiastic, and focus } \\
\text { on relationships. Not interested in long-term careers and have limited corporate } \\
\text { loyalty or status. Have an open-to-change attitude, adaptable, technologically } \\
\text { literate, independent, creative, and not intimidated by authority. They respond to } \\
\text { instant gratification and they work to live. }\end{array}$ \\
\hline $\begin{array}{l}\text { Optimistic, confident, strong morals and ethics. Expect greater workplace } \\
\text { flexibility, enjoy brainstorming and challenges, and want everything to be } \\
\text { mobile, fast, accurate, and at their fingertips. Mobile-orientated, technologically } \\
\text { informed, and able to multitask. "The more, the merrier"; "Rules are made to be } \\
\text { broken"; "Here today and gone tomorrow". }\end{array}$ \\
\hline
\end{tabular}


Although cognisance is taken of the different generational cohorts as defined by generational cohort theory, only three cohorts were included in this study, namely the Baby Boomers, Generation X, and Generation Y. The rationale for this choice of cohorts is that the sample was drawn from the South African labour force, which may be regarded as a "population of working age people that is working or that wants to work" (Barker, 2015:9). Since the Traditionalists were born between 1930 and 1949 (Gursoy et al., 2008:451; Robbins et al., 2009:102; Roux, 2008:20), they would represent pensioners and were therefore not included in the study.

\section{Work ethics}

Work ethics are attitudes and beliefs concerning work behaviour, and is a multidimensional construct reflected in decision making and behaviour (Miller et al., 2002:453; Ravangard, Sajjadnia, Jafari, Shahsavan, Bahmaie \& Bahadori, 2014:3). Thus, employees' work ethics may be regarded as the overall framework from which work values emanate, which, in turn, influences individuals' behaviour at work. In the current study, work ethics were measured using the Multidimensional Work Ethic Profile (MWEP). The reason for this choice of instrument was that the MWEP has previously been used to measure work ethics internationally (Van Ness, Melinsky, Buff \& Seifert, 2010:25) as well as in South Africa (Kwizera, 2011:91). The MWEP is a 65-item scale that was developed to "measure seven conceptually and empirically distinct facets of the work ethic construct" (Miller et al., 2002:1). The seven facets are self-reliance, morality/ethics, leisure, hard work, centrality of work, wasted time, and delay of gratification.

Self-reliance refers to a striving for independence in one's everyday work (Miller et al., 2002:14), or depending on oneself and not relying on others (Dwyer, 2012:103). Some scholars (e.g. Simons, 2010:29) have characterised Generation X as self-reliant and individualistic, while Generation $Y$ has been described as self-inventive and individualistic.

Morality and ethics, as measured by the MWEP, is regarded as one facet of work ethics, which refers to "beliefs pertaining to a just and moral existence" (Miller et al., 2002:11). However, morality and ethics are often considered as separate constructs, where morality refers to customs or manners that are usually applied to one's behaviour, and ethics relates to an individual's character (Chidi, Ogunyomi \& Badejo, 2012:117). Nonetheless, the two concepts are often used interchangeably to refer to the way individuals behave in the work context, or the way they are expected to behave (Van Ness et al., 2010:14). Verschoor (2013:12) reports that a study conducted in the United States found that Generation $\mathrm{Y}$ often perceived unethical behaviour as ethical, which could result in this generational cohort interpreting this dimension of work ethics differently from other generational cohorts.

Leisure refers to pro-leisure attitudes and a belief in the importance of non-work activities, such as spending time relaxing (Miller et al., 2002:14) or indulging in personally meaningful and pleasurable activities (Chun, Lee, Kim \& Heo, 2012:440). According to 
Twenge (2010:208), the findings of previous research have shown that Generation X and Generation $\mathrm{Y}$ are more likely to value leisure and are less willing to work hard.

Hard work may be understood as a belief in the virtue of hard work (Miller et al., 2002:14), or the belief that one can become a better person and achieve objectives through a commitment to the value and importance of work (Van Ness et al., 2010:16). It seems that younger employees and older employees may differ in their perceptions of what constitutes hard work as well as in their personal aspirations. As such, previous research indicates that hard work is not as important to younger employees as it is to older employees (ibid.:16). Tolbize (2008:8) also reports generational differences with regard to hard work, indicating that the Baby Boomers are workaholics, while Generation X will only work as hard as is required.

Centrality of work refers to a belief in work for work's sake (Miller et al., 2002:14); the degree of importance that working has in the life of an individual at any given point in time; or the meaning of work (Schreuder \& Coetzee, 2011:6). With regard to work centrality, Van Ness et al. (2010:17) report that professionals have a greater orientation towards work centrality than students, possibly because of the responsibilities that they face at the particular stage of life that they find themselves in, which stimulates a sense of work centrality. Twenge (2010:208) asserts that Generation X and Generation Y rate work as less central to their lives, while leisure is rated higher. Schreuder and Coetzee (2011:6) state that when leisure time increases, centrality of work decreases.

Wasted time relates to attitudes and beliefs that reflect an active and productive use of time (Miller et al., 2002:14); i.e. not wasting time on activities that will not result in production of valuable goods or services (Horman \& Kenley, 2005:52). Van Ness et al. (2010:18) explain that wasted time in the context of work ethics can be conceived as a continuum, with high commitment to time management at one end of the continuum and low commitment at the other. Regarding time management, Gursoy et al. (2008:158) reported that Baby Boomers are generally committed to their work and would rather work longer hours than leave work incomplete. Generation X prefers less demanding jobs with stable working hours, as this allows them to spend adequate time with their families (ibid.:455). Generation $X$ are also more inclined to appreciate opportunities to divide their time appropriately between work, family and recreational activities, while Generation $Y$ generally values flexibility in their work scheduling and work programmes (Van der Walt \& Du Plessis, 2010:4).

Delay of gratification pertains to a future orientation and postponement of rewards (Miller et al., 2002:14); in other words, sacrificing short-term rewards in order to achieve long-term objectives (Abd-El-Fattah \& AL-Nabhani, 2012:93). The information presented in Table 1, for example, indicates that Generation $Y$ values instant gratification. This has mainly been attributed to the fact that Generation $Y$ grew up in a time of technological advances and social media, which afforded them access to immediate or instant feedback and rewards (Codrington \& Grant-Marshall, 2006:19). However, other studies have indicated that it is not only Generation $Y$ who values instant gratification, but rather all generational cohorts (Govitvatana, 2001:11; Schultz, Schwepker Jr \& Good, 2012:35). 
In light of the above discussion it is clear that generational cohorts differ in terms of the dimensions that encompass work ethics. Although it would be to an organisation's advantage to develop employees with respect to dimensions such as hard work and wasted time, organisations cannot ensure ethical behaviour through the provision of training and development initiatives. However, it does seem important that they should develop guidelines to assist employees to become more aware of ethical conduct. This will ensure that employees are aware of the basic principles and standards that they are expected to abide by, as well as the boundaries of acceptable conduct (Mafunisa, 2008:83). Bergh (2011:247) asserts that an organisation's reputation with regard to ethical behaviour will have an impact on the type of prospective employees who apply for vacancies at the organisation.

The aim of this study was to identify the work ethics that are important to different generations in a developing country, and to establish whether statistically significant differences exist between different generational cohorts in terms of work ethics. The aforementioned aim was investigated using the following research hypothesis: Statistically significant differences exist between different generational cohorts in terms of work ethics.

\section{Research design and methods}

For the purposes of this study, the positivist research paradigm was adopted, as the study relied on empirical data. A cross-sectional quantitative research design was employed to investigate the research hypothesis that was prompted by the nature of the study. Hence, data was collected once-off by means of the Multidimensional Work Ethic Profile (MWEP) survey referred to in the preceding section on work ethics. Individuals were the unit of analysis, and the population parameter was working-age individuals who were either working or currently unemployed.

South African organisations were approached to participate in the study, and three organisations in different sectors but situated in one district within South Africa confirmed their willingness to participate. In addition to the working population, senior students with some work experience who were enrolled in the Faculty of Management Sciences at a university of technology in the same area were included in the sample. The reason for their inclusion was their willingness to participate in the study, as well as logistical factors that made it conducive to use them. Thus, convenience sampling was used to select participants from the population, since only available individuals of the target population could be included. The use of convenience sampling allowed for inclusion of participants from all generational cohorts and precluded coerced participation.

Data was collected from respondents by means of a self-administered structured questionnaire, as this is deemed an acceptable method of data collection to use when literate individuals are the unit of analysis in a study (Mathers, Fox \& Hunn, 2009:19). The questionnaire consisted of two sections, namely a biographical section and a section containing questions to measure work ethics. The first section included five questions 
related to the respondents' race, gender, age (to determine the respondent's generational cohort), years of service with the current organisation, and highest academic qualification.

As mentioned, the MWEP was used to measure work ethics. As previously mentioned, the MWEP is a 65-item scale that was developed to "measure seven conceptually and empirically distinct facets of the work ethic construct" (Miller et al., 2002:1). The seven constructs are identified as hard work, self-reliance, leisure, centrality of work, morality/ ethics, delay of gratification, and wasted time (ibid.:12). Participants were requested to select the most appropriate option from a five-point Likert scale, with options ranging from 'Strongly agree' (1) to 'Neutral' or 'Not applicable' (3) to 'Strongly disagree' (5). Miller et al. (ibid.:30) assert that the MWEP is a reliable measure of overall work ethics and the dimensions thereof. A Cronbach's alpha coefficient was determined to measure the reliability of the MWEP for the current sample. The Cronbach's alpha coefficient was 0.94, indicating very high reliability (Salkind, 2012:208).

The questionnaires were distributed personally by the researcher and collected again within fourteen days of distributing them, allowing the respondents sufficient time to complete the questionnaire in their own time and at their own convenience. Respondents were requested to put the questionnaires in a sealed envelope upon completion, and the researcher collected the completed questionnaires personally from the respondents at a central point, thereby ensuring confidentiality. Due care was given to ethical considerations such as informed consent, confidentiality, voluntary participation and anonymity during the data collection stage of the research. In addition, it should be noted that the consent of gatekeepers was obtained at various levels, including the research ethics committee of the higher education institution under whose auspices the research was conducted and the management of the participating organisations.

A total of 540 questionnaires were distributed. According to Babbie (2001:256), when conducting a mail survey, a response rate of $50 \%$ may be deemed adequate for purposes of analysis and reporting, while a response rate of $60 \%$ may be regarded as good. In total, 301 completed questionnaires were returned, which equates to a $55.7 \%$ response rate. Hence, the final sample consisted of 301 respondents, who varied in terms of sociodemographic variables. The employment status of the respondents was distributed almost evenly, with $170(56.5 \%)$ of the respondents being unemployed and 131 (43.5\%) working at the time of the survey. The gender distribution was skewed towards females, who accounted for $62.5 \%(n=188)$ of the respondents, while $37.2 \%(n=112)$ of the sample were males. The majority of the sample consisted of black African respondents $(n=275 ; 91.4 \%)$, followed by whites $(n=17 ; 5.6 \%)$, Coloureds $(n=7 ; 2.3 \%)$, and Indians/Asians $(n=1 ; 0.3 \%)$.

With regard to age, the majority of the respondents belonged to Generation $Y(n=155$; $51.5 \%)$; followed by Generation X $(n=112 ; 37.2 \%)$; and the Baby Boomers $(n=34 ; 11.3 \%)$. Most of the respondents had 0 to 1 year of service $(n=133 ; 44.2 \%)$ at their current organisation. With regard to educational attainment, the majority of respondents had a Grade 12 qualification $(n=189 ; 62.8 \%)$, followed by respondents with a national diploma $(n=7 ; 23.3 \%)$ and those with an honours degree or equivalent $(n=23 ; 7.6 \%)$. The rationale for including different levels of educational attainment in the sample was based on previous research findings. In this regard, Chow and Choi (2003:119) reported that 
respondents with higher levels of education demonstrated more ethical behaviour than other respondents.

\section{Data analysis}

Descriptive and inferential statistics were computed to determine the relationship between age (divided according to the generational cohorts) and the dependent variable, namely work ethics. More specifically, a Kruskal-Wallis test was performed, due to the fact that the distribution was not normal.

\section{Findings}

The measures of central tendency, including the mean, the median, the standard deviation, and the maximum and minimum scores for each generational cohort are depicted in Tables 3 to 5, starting with Generation Y.

Table 3: Measures of central tendency for Generation $Y$ for facets of work ethics

\begin{tabular}{l|c|c|c|c|c}
\hline \multicolumn{1}{c|}{ Facet of work ethics } & Min & Max & Median & Mean & SD \\
\hline Self-reliance & 1 & 3 & 2.00 & 2.01 & 0.50 \\
\hline Morality/ethics & 4 & 5 & 4.50 & 4.47 & 0.332 \\
\hline Leisure & 3 & 5 & 3.75 & 3.8 & 0.502 \\
\hline Hard work & 1 & 3 & 1.50 & 1.57 & 0.453 \\
\hline Centrality of work & 1 & 5 & 2.10 & 2.13 & 0.597 \\
\hline Wasted time & 1 & 4 & 2.00 & 1.99 & 0.559 \\
\hline Delay of gratification & 1 & 5 & 2.00 & 2.06 & 0.593 \\
\hline
\end{tabular}

The work ethics subscale of hard work had the lowest mean score (mean =1.57), which indicates that hard work was of very low importance to Generation Y. The subscales of self-reliance, centrality of work, wasted time and delay of gratification had mean scores ranging from 1.99 to 2.06, indicating that these facets of work ethics were of low importance to Generation Y. The subscale of leisure had a mean score of 3.8, which indicates that leisure was of high importance to this generational cohort, while morality/ ethics had a mean score of 4.47, indicating that Generation $\mathrm{Y}$ attached very high importance to this subscale.

Table 4: Measures of central tendency for Generation $X$ for facets of work ethics

\begin{tabular}{l|c|c|c|c|c}
\hline \multicolumn{1}{c|}{ Facet of work ethics } & Min & Max & Median & Mean & SD \\
\hline Self-reliance & 1 & 4 & 2.00 & 2.10 & 0.568 \\
\hline Morality/ethics & 4 & 5 & 4.6 & 4.55 & 0.370 \\
\hline Leisure & 3 & 5 & 3.83 & 3.83 & 0.484 \\
\hline Hard work & 1 & 4 & 1.50 & 1.61 & 0.565 \\
\hline Centrality of work & 1 & 4 & 2.00 & 2.07 & 0.626 \\
\hline Wasted time & 1 & 5 & 2.00 & 2.00 & 0.649 \\
\hline Delay of gratification & 1 & 5 & 2.14 & 2.17 & 0.705 \\
\hline
\end{tabular}


Similar to Generation Y, Generation X indicated that hard work was of very low importance $($ mean $=1.61)$. In addition, four work ethics subscales had mean scores ranging from 2.0 to 2.17 , namely wasted time, self-reliance, centrality of work, and delay of gratification, which indicates that these facets of work ethics were of low importance to Generation X. Similar to Generation Y, leisure was perceived as of high importance to Generation $X($ mean $=3.83)$, followed by morality/ethics, which was regarded as of very high importance $($ mean $=4.55)$.

Table 5: Measures of central tendency for the Baby Boomer cohort for facets of work ethics

\begin{tabular}{l|c|c|c|c|c}
\hline \multicolumn{1}{c}{ Facet of work ethics } & Min & Max & Median & Mean & SD \\
\hline Self-reliance & 1 & 4 & 2.20 & 2.23 & 0.551 \\
\hline Morality/ethics & 3 & 5 & 4.60 & 4.50 & 0.395 \\
\hline Leisure & 3 & 5 & 3.67 & 3.60 & 0.520 \\
\hline Hard work & 1 & 5 & 1.85 & 1.89 & 0.643 \\
\hline Centrality of work & 1 & 4 & 2.20 & 2.15 & 0.574 \\
\hline Wasted time & 1 & 4 & 1.86 & 1.91 & 0.461 \\
\hline Delay of gratification & 2 & 5 & 2.29 & 2.42 & 0.577 \\
\hline
\end{tabular}

The results of the Baby Boomer cohort indicated that five of the work ethics subscales were of low importance to this group, with mean scores ranging from 1.89 to 2.42. These subscales were self-reliance, hard work, centrality of work, wasted time, and delay of gratification. The work ethics that were the most important to the Baby Boomers were morality/ethics, with a mean score of 4.50, and leisure, with a mean score of 3.60.

From the above findings, it would appear that there are similarities and differences between the generational cohorts in their evaluation of the measured facets of work ethics. In order to establish whether statistically significant differences exist among the generational cohorts in terms of work ethics, a Kruskal-Wallis test was performed. The results of this test are depicted in Table 6.

Table 6: Kruskal-Wallis test results for work ethics as dependent variable and generational cohort as independent variable

\begin{tabular}{l|c|c|c}
\hline \multicolumn{1}{c}{ Level of the variable } & Chi-square & df & p \\
\hline Self-reliance & 4.320 & 2 & 0.115 \\
\hline Morality/ethics & 4.830 & 2 & 0.089 \\
\hline Leisure & 4.531 & 2 & 0.104 \\
\hline Hard work & 9.645 & 2 & $0.008^{* *}$ \\
\hline Centrality of work & 2.180 & 2 & 0.336 \\
\hline Wasted time & 0.876 & 2 & 0.645 \\
\hline Delay of gratification & 11.346 & 2 & $0.003^{* *}$ \\
\hline
\end{tabular}

${ }^{* *} p \leq 0.01$

Statistically significant differences were found for hard work and delay of gratification. With regard to hard work, the Baby Boomer cohort had the highest mean ranking (mean 
ranking $=194.51)$, while Generation $X($ mean ranking $=146.33)$ and Generation $Y$ (mean ranking $=144.83$ ) differed by only a small margin. Thus, the Baby Boomer cohort valued hard work more than the other two groups. Similarly, with regard to delay of gratification, the Baby Boomer cohort had the highest mean ranking (mean ranking $=194.68$ ), followed by Generation X (mean ranking $=153.45)$ and Generation $Y($ mean ranking $=139.65)$. It should also be noted that a post-hoc test could not be performed, as a non-parametric test was used to compute the results presented.

\section{Discussion}

The findings regarding the work ethics of the different generational cohorts (see Tables 1 to 3) show some similarities and some differences across the generational cohorts. With regard to similarities between the seven work ethics measured, leisure and morality/ ethics are important to all the generational cohorts. With regard to leisure, the research findings confirm the findings of Twenge (2010:208), who asserted that previous research had indicated that all generations are more likely to value leisure over hard work. However, the findings show some inconsistency with the findings of previous research by Schreuder and Coetzee (2011:15), which indicated that the Baby Boomers do not value leisure time as much as Generation $\mathrm{X}$ and Generation Y. Secondly, the findings indicated that all three generational cohorts deemed morality/ethics to be the most important facet of work ethics. The findings of the current study with regard to morality/ethics disconfirm previous research findings; for example, Twenge (2010:204) asserted that most previous studies had found that Generation X and Generation $Y$ have weaker work ethics.

In terms of differences, and specifically the research hypothesis - i.e. that statistically significant differences exist between various generational cohorts with regard to work ethics - two statistically significant differences were noted, namely hard work and delay of gratification. With regard to hard work, the literature indicates that Baby Boomers are perceived as workaholics who will stay at work until they have got the job done, and who will thus spend more time at work than at home (Shragay \& Tziner, 2011:144). The findings of the current study confirm that the Baby Boomers do indeed value hard work more than the other two generational cohorts. Disconfirming the literature that characterises Generation X as "slackers" (see Codrington \& Grant-Marshall, 2006), the current study shows only a small difference between Generation $X$ and Generation $Y$ with regard to the importance of hard work. In fact, the findings indicate that the importance of hard work is nearly the same for both Generation X and Generation Y, and is only slightly higher for the Baby Boomers.

With regard to delay of gratification, the findings of the current study contradict the findings of previous research, which indicate that all generational cohorts value instant gratification (Govitvatana, 2001:11; Schultz et al., 2012:35). The findings of the current study indicate that the various generational cohorts significantly differed statistically in terms of delay of gratification. Thus, the Baby Boomer cohort most valued delay of gratification, followed by Generation X, while Generation $Y$ valued delay of gratification least of all. It is therefore possible that Generation $Y$ may value instant gratification. 
One explanation for the difference in findings regarding this facet of work ethics may be that the current sample is becoming increasingly concerned about the future due the country's poor economic performance, hence the low importance that Generation $Y$ attached to delay of gratification.

In light of the differences noted, the null hypothesis is rejected.

\section{Generational profile of work ethics for a South African sample}

A profile of work ethics in order of priority for a South African sample is depicted in Table 7.

Table 7: Work ethics profile of different generational cohorts working within the South African work environment

\begin{tabular}{|c|c|c|}
\hline Cohort & Born between & Work ethics \\
\hline Generation Y & $1990-2000$ & $\begin{array}{l}\text { - Morality / Ethics } \\
\text { - Leisure } \\
\text { - Centrality of work } \\
\text { - Delay of gratification } \\
\text { - Self-reliance } \\
\text { - Wasted time } \\
\text { - Hard work }\end{array}$ \\
\hline Generation X & 1970-1989 & $\begin{array}{l}\text { - Morality / Ethics } \\
\text { - Leisure } \\
\text { - Delay of gratification } \\
\text { - Self-reliance } \\
\text { - Centrality of work } \\
\text { - Wasted time } \\
\text { - Hard work }\end{array}$ \\
\hline Baby Boomers & 1950-1969 & $\begin{array}{l}\text { - Morality / Ethics } \\
\text { - Leisure } \\
\text { - Delay of gratification } \\
\text { - Self-reliance } \\
\text { - Centrality of work } \\
\text { - Wasted time } \\
\text { - Hard work }\end{array}$ \\
\hline
\end{tabular}

\section{Limitations of the study}

The following limitations should be taken into consideration when interpreting the findings of this study. Firstly, convenience sampling was used to generate the sample, which adversely influenced the external validity of the study. Secondly, it is estimated that the Free State province has a population size of 2745590 million, while the specific target area had a population size of 64130 . Thus, a sample of 384 or 381 would have been representative of the population, at the 95th level of confidence, with a $5 \%$ margin of error. As a result, it should be noted that the sample was neither representative of the target area nor the target province where the research was conducted. Caution is consequently advised when interpreting the results presented above. Despite these limitations, the 
study provides valuable insights into the work ethics of the various generational cohorts, and it can be used as a point of departure to stimulate further research within the South African context.

\section{Conclusions}

Most previous studies investigating the relationship between generational cohorts and work ethics have been conducted in First World countries. Unfortunately, sufficient empirical studies have not been conducted in developing countries with regard to different generational cohorts that currently exist or are about to enter organisations. It is for this reason that this study reported on generational differences regarding work ethics for a South African sample.

The facets of work ethics identified as being important to the three generational cohorts of the current sample differed from those identified by previous research studies in developed countries. However, the biographical data of the sample indicated that the majority of the respondents were of African descent. The findings of the study suggest differences in work ethics between developed countries and developing countries, as well as between generations of different descent (i.e. African and European). Consequently, further research is recommended to determine the generational differences in terms of work ethics and other variables between European and African countries. It is further recommended that studies be conducted to investigate perceptions of work ethics among Africans. One may also consider how Africans understand and conceptualise the construct of work ethics and its dimensions.

The most significant finding of the study was that all three generational cohorts included in the study valued morality/ethics as the most important facet of work ethics. This is an interesting finding, taking into consideration that South Africa has been stereotyped as a violent, aggressive and corrupt society where unethical behaviour is rife. In order to create more awareness of ethical behaviour, organisations should therefore mindfully consider creating strong ethical organisational cultures that are authentically embodied by organisational leaders. Furthermore, irrespective of their generational cohort, employees should receive morality and ethics mentoring so as to create a common understanding of this work ethic. Similarly, new employees entering the workplace need to be coached through induction programmes so as to maintain strong ethical organisational cultures that are embraced by all members within the organisation.

Hard work as a facet of work ethics was not considered important by any of the generational cohorts. This may encourage members of organisations to take short cuts to achieve goals, thereby maximising outcomes while minimising inputs. This finding may pose a problem for traditional organisational leaders, as in the past organisational performance has often been found to be positively correlated with hard work, and hard work has been rewarded. However, it may be possible that contemporary employees focus on 'working smarter, not harder' due to technological advances and other factors. Therefore, organisations should consider becoming more flexible in terms of strict 
adherence to company policies and procedures. This will require that current stringent policies and procedures be reconsidered in order to establish their usefulness and relevance in the contemporary workplace and to present-day employees. Based on the findings of the study, it is recommended that future research should focus on validating the current findings as well as extending the investigation to a larger sample, so as to advance the current limited body of knowledge concerning generational differences in terms of work ethics in developing countries.

\section{References}

Abd-El-Fattah, S.M. \& AL-Nabhani, H.Z. 2012. From self-theories of intelligence to academic delay of gratification: The mediating role of achievement goals. Australian Journal of Educational and Developmental Psychology, 12:93-107.

Babbie, E. 2001. The practice of social research. (9th Edition). Belmont, CA: Wadsworth/Thomson Learning.

Barker, F.S. 2015. The South African labour market: Theory and practice. (5th Revised Edition). Pretoria: Van Schaik.

Bell, S.T., Villado, A.J., Lukasik, M.A., Belau, L. \& Briggs, A.L. 2011. Getting specific about demographic diversity variable and team performance relationships: A meta-analysis. Journal of Management, 37(3):709-743. DOI: 10.1177/0149206310365001

Bergh, Z.C. (ed.). 2011. Introduction to work psychology. Cape Town: Oxford University Press South Africa.

Bevan-Dye, A.L. 2012. Relationship between self-esteem and facebook usage amongst black Generation Y students. African Journal for Physical Health Education, Recreation and Dance, Supplement 1(1):33-49.

Burke, M.E. 2004. Generational Differences. Survey Report.VA, USA: Society for Human Resource Management Department.

Chidi, O.C., Ogunyomi, O.P. \& Badejo, A.E. 2012. Promoting ethical human resource management practices in work organisations in Nigeria: Roles of HR professionals. International Journal of Human Resource Studies, 2(2):116-131.

Chow, W.S. \& Choi, K.Y. 2003. Identifying managers who need ethics training in using IT at work. Behaviour and Information Technology, 22(2):117-125. DOI: 10.1080/0144929031000088416

Chun, S., Lee, Y., Kim, B. \& Heo, J. 2012. The impact of leisure participation and leisure satisfaction on stressrelated growth. Leisure Sciences, 34(5):436-449. DOI: 10.1080/01490400.2012.714704

Codrington, G. \& Grant-Marshall, S. 2006. Mind the gap. Cape Town: Penguin.

Davis, J.A. 2009. Did growing up in the 1960s leave a permanent mark on attitudes and values? Evidence from the General Social Survey. The Public Opinion Quarterly, 68(2):161-183. DOI: 10.1093/poq/nfh010

De Wit, F.R.C., Greer, L.L. \& Jehn, K.A. 2012. A meta-analysis of the relationship between diversity, conflict and team performance. Journal of Applied Psychology, 92(2). http://works.bepress.com/etty_jehn/35/ [Accessed: 16 February 2015].

Dwyer, T. 2012. Legal and ethical issues in the media. Basingstoke, Hampshire, UK: Palgrave Macmillan.

Govitvatana, W.V. 2001. Generation gap in the workplace between Baby Boomers and Generation X. MSc thesis. Menomonie, WI: University of Wisconsin-Stout.

Gursoy, D., Maier, T.A. \& Chi, C.G. 2008. Generational differences: An examination of work values and generational gaps in the hospitality workforce. International Journal of Hospitality Management, 27(3):448-458. DOI: 10.1016/j.ijhm.2007.11.002

Horman, M.J. \& Kenley, R. 2005. Quantifying levels of wasted time in construction with meta-analysis. Journal of Construction Engineering and Management, 131(1):52-61. DOI: 10.1061/(ASCE)0733-9364(2005)131:1(52)

Jonck, P. \& Swanepoel, E. 2015. Exploring the theoretical link between cultural and emotional intelligence: A system analysis for human resource management. South African Journal of Business Management, 46(4):77-83. 
Kwizera, A.S. 2011. Quality of work and work life: Understanding the work ethic of medical professionals in selected hospitals in the Eastern Cape region of South Africa. PhD thesis. Grahamstown: Rhodes University.

Mafunisa, M.J. 2008. The role of codes of conduct in promoting ethical conduct in the South African public service. South African Journal of Labour Relations, 32(1):81-92.

Mannheim, K. 1964. Über das Wesen und die Bedeuteng des wirtschaftlichen Erfolgsstrebens. Ein Betrag zur Wirtschaftssoziologie (zuerst 1930). In: Wolff, K.H. (ed.). Wissenssoziologie. Auswahl aus dem Werk. Berlin/ Neuwied: Luchterhand. 625-687.

Mathers, N., Fox, N \& Hunn, A. 2009. Surveys and Questionnaires. The NIHR RDS for the East Midlands/ Yorkshire \& the Humber. https://www.rds-yh.nihr.ac.uk/wp-content/uploads/2013/05/12_Surveys_and_ Questionnaires_Revision_2009.pdf [Accessed: 13 June 2016].

Meriac, J.P., Woehr, D.J. \& Banister, C. 2010. Generational differences in work ethic: An examination of measurement equivalence across three cohorts. Journal of Business and Psychology, 25(2):315-324. DOI: 10.1007/s10869-010-9164-7

Miller, M.J., Woehr, D.J. \& Hudspeth, N. 2002. The meaning and measurement of work ethic: Construction and initial validation of a multidimensional inventory. Journal of Vocational Behaviour, 60(3):451-489. DOI: $10.1006 /$ jvbe.2001.1838

Napoli, A. 2014. Social media use and generational identity: Issues and consequences on peer-to-peer and cross-generational relationships - An empirical study. Participations: Journal of Audience and Reception Studies, 11(2):182-206.

Patel, K. 2013. Analysis: Perceptions and reality of corruption in South Africa. Daily Maverick, 5 December. http://www.dailymaverick.co.za/article/2013-12-05-analysis-perceptions-and-reality-of-corruption-insouth-africa/\#.U-tpt-OSySo [Accessed: 13 August 2014].

Ravangard, R., Sajjadnia, Z., Jafari, A., Shahsavan, N., Bahmaie, J. \& Bahadori, M. 2014. The association between work ethics and attitudes towards organizational changes among the administrative, financial and support employees of general teaching hospitals. Journal of Medical Ethics and History of Medicine, 7(12):1-9.

Robbins, S., Judge, T.A., Odendaal, A. \& Roodt, G. 2009. Organisational behaviour: Global and Southern African perspectives. (2nd Edition). Cape Town: Pearson Education South Africa.

Roux, D.F. 2008. Approaches, expectations and perceptions of different generations regarding culture and leadership in the Engineering Department at Sishen Mine. MBA thesis. Stellenbosch: University of Stellenbosch.

Salkind, N.J. (ed.). 2012. Exploring research. (8th Edition). New York, NY: Pearson.

Schreuder, A.M.G. \& Coetzee, M. 2011. Careers: An organisational perspective. (4th Edition). Cape Town: Juta.

Schultz, R.J., Schwepker, C.H. Jr \& Good, D.J. 2012. Generational research in the sales arena. Innovative Marketing, 8(1):8-14.

Shragay, D. \& Tziner, A. 2011. The generational effect on the relationship between job involvement, work satisfaction, and organizational citizenship behavior. Journal of Work and Organizational Psychology, 27(2):143-157.

Simons, N. 2010. Leveraging generational work styles to meet business objectives. Information Management, 44(1):28-33.

Strydom, J.B. \& Erwee, R. 1998. Diversity management in a sample of South African organisations. South African Journal of Business Management, 29(1):14-20.

Tolbize, A. 2008. Generational differences in the workplace. Minneapolis, MN: Research and Training Center on Community Living, University of Minnesota. http://rtc.umn.edu/docs/2_18_Gen_diff_workplace.pdf [Accessed: 10 June 2015].

Triandis, H.C. 2006. Cultural intelligence in organizations. Group and Organization Management, 31(1):20-26. DOI: $10.1177 / 1059601105275253$

Twenge, J.M. 2010. A review of the empirical evidence on generational differences in work attitudes. Journal of Business and Psychology, 25(2):201-210. DOI: 10.1007/s10869-010-9165-6 
Van der Walt, S. \& Du Plessis, T. 2010. Leveraging multi-generational workforce values in interactive information societies. South African Journal of Information Management, 12(1):1-7. DOI: 10.4102/sajim. v12i 1.441

Van Ness, R.K., Melinsky, K., Buff, C.L. \& Seifert, C.F. 2010. Work ethic: Do new employees mean new work values? Journal of Managerial Issues, 22(1):10-34.

Verschoor, C.C. 2013. Ethical behavior differs among generations. Strategic Finance, August: 11-13.

Wolf, M.M.G., Carpenter, S. \& Qenani-Petrela, E. 2005. A comparison of X, Y and Boomer generation wine consumers in California. Journal of Food Distribution Research, 36(1):186-191. 